\title{
Satisfaction, Perspective, and Attitude Toward E-learning among Emergency Medicine Physicians
}

\author{
Acil Tıp Hekimlerinin E-öğrenmeye Yönelik Memnuniyetleri, Bakış Açıları ve \\ Tutumları
}

(1) Göksu Bozdereli Berikol, (1) Buğra İlhan, (1) Halil Doğan

University of Health Sciences Turkey, Bakırköy Dr. Sadi Konuk Training and Research Hospital, Clinic of Emergency Medicine, Istanbul, Turkey

\begin{abstract}
Objective: E-learning gained popularity since the sudden pandemic entry, which revealed the need to adapt to our practice after becoming mandatory. Thus, this study aimed to investigate the perceptions toward e-learning among emergency medicine physicians.

Methods: In this questionnaire-based cross-sectional study, an online questionnaire was given about demographics, self-efficacy, satisfaction, self-control, anxiety, perceived usefulness, and attitudes toward e-learning was conducted on emergency medicine residents and specialists who are remotely involved in emergency medicine training in their departments due to the pandemic. The self-efficacy, satisfaction, interactivity, perceived ease of use, perceived benefit, self-control, and attitude scores were calculated based on the total Likert points of statements, and correlations were analyzed.

Results: This study included 74 participants who remotely performed emergency medicine training during the study. Experience in years showed statistically higher satisfaction ( $p=0.018)$, self-control $(p=0.003)$, ease of use $(p=0.042)$, perception of benefit $(p=0.022)$, and attitude $(p=0.030)$ rates in residents. Experienced participants has a statistically lower self-efficacy $(p=0.044)$ and higher perception of ease of use $(p=0.034)$. Perception of benefit $(p=0.009)$, self-control $(p=0.006)$, perception of ease of use $(p=0.01)$, and attitude $(p=0.018)$ was statistically higher in high computer skill levels. Perception of benefit $(r=0.543)$ is associated with higher computer skill levels, satisfaction $(r=0.407)$, and perception of interactivity $(r=0.498)$. Satisfaction had a positive correlation with self-control $(r=0.543, p=0.000)$ and benefit perception $(r=0.543, p=0.000)$.

Conclusion: Increased interaction, improved users' computer skills and maintained higher self-efficacy and benefit perception are important to increase the satisfaction and adoption with e-learning.
\end{abstract}

Keywords: E-learning, emergency medicine, distance learning, satisfaction

\section{öz}

Amaç: E-öğrenme, pandeminin girişinden bu yana popülerlik kazandı. Zorunlu hale geldiğinde, pratiğe uyum sağlama ihtiyacını da ortaya çıkardı. Çalışmamız acil tıp hekimlerinin e-öğrenmeye yönelik algılarını araştırmayı amaçlamıştır.

Gereç ve Yöntem: Bu kesitsel anket çalışması süresince pandemi nedeni ile acil tıp eğitimini kliniklerinde uzaktan eğitim uygulayan acil tıp asistanları ve acil tıp uzmanlarına öz yeterlilik, memnuniyet, öz kontrol, kaygı, algılanan fayda ve e-öğrenmeye yönelik tutumlarla ilgili bir anket uygulandı. Ifadelerin toplam Likert puanlarına göre öz yeterlik, memnuniyet, interaktivite, kullanım kolaylığı algısı, fayda algısı, öz kontrol ve tutum puanları hesaplanmış ve korelasyonları analiz edilmiştir.

Bulgular: Çalışma süresince acil tıp eğitimini uzaktan gerçekleştiren 74 katılımcı çalışmaya dahil edildi. Yıllara göre deneyim, asistanlarda istatistiksel olarak daha yüksek memnuniyet $(p=0,018)$, kendini kontrol $(p=0,003)$, kullanım kolaylığı $(p=0,042)$, fayda algısı ( $p=0,022)$ ve tutum $(p=0,030)$ göstermiştir. Deneyimli katılımcılar istatistiksel olarak daha düşük öz-yeterlik $(p=0,044)$ ve daha yüksek kullanım kolaylığı algısı $(p=0,034)$ idi. Fayda algısı $(p=0,009)$, özdenetim $(p=0,006)$, kullanım kolaylığı algısı $(p=0.01)$, tutum $(p=0.018)$ yüksek bilgisayar beceri düzeylerinde istatistiksel olarak daha yüksekti. Fayda algısı $(r=0,543)$ daha yüksek bilgisayar beceri seviyeleri ile ilişkilidir; memnuniyet $(r=0,407)$ ve etkileşim algısı $(r=0,498)$. Memnuniyet ile öz kontrol $(r=0,543, p=0,000)$ ve fayda algısı $(r=0,543, p=0,000)$ arasında pozitif bir ilişki vardı.

Sonuç: Memnuniyeti ve e-öğrenmeye uyumu artırmak için etkileşimi artırmak, kullanıcıların bilgisayar becerilerini geliştirmek ve daha yüksek özyeterlik ve fayda algısını sürdürmek önemlidir.

Anahtar Kelimeler: E-öğrenme, acil tıp, uzaktan öğrenme, memnuniyet

Address for Correspondence: Göksu Bozdereli Berikol, University of Health Sciences Turkey, Bakırköy Dr. Sadi Konuk Training and Research Hospital, Clinic of Emergency Medicine, Istanbul, Turkey

Phone: +90 5534803384 E-mail: gokxsu@hotmail.com ORCID ID: orcid.org/0000-0002-4529-3578

Cite as: Bozdereli Berikol G, IIlhan B, Doğan H. Satisfaction, Perspective, and Attitude Toward E-learning among Emergency Medicine Physicians. Med J Bakirkoy 2021;17:400-406

Received: 25.10 .2021

Accepted: 2.12 .2021 


\section{INTRODUCTION}

Distance education is a form of education that brings students, teachers, and course resources together in different places using technology, which enables communication among them (1). With today's technologies, education is carried to different platforms online or offline, simultaneous, or independent of time. It has been used with names, such as online, e-learning, web-based learning, and virtual learning. This concept, which was first introduced in 1892 at the University of Wisconsin of the United States, was firstly used in our country in 1956 (2).

\section{Theoretical Framework}

User's perceptions and attitudes toward e-learning technologies are essential in the success of the educational process (3). Self-efficacy and satisfaction have a role in the achievement and motivational mechanisms (4). User satisfaction is defined as the point where competence is sought, wherein satisfaction is "the state of being above an expectation level that is expressed by the user" (5). Bandura's Social Cognitive Theory defined self-efficacy as "an individual's belief in his or her own ability to organize and implement action to produce the desired achievements and results" $(4,6)$. The other factors that affect the acceptance of technology include perceived benefit and ease of use. Leung referred to perceived benefit as "the perception of the positive consequences that are caused by a specific action" (7), whereas perceived ease of use is defined as "the degree to which a person believes that using a particular system would be free of effort" (8). The standardized scales are developed to measure these perceptions and factors for technology acceptance (2,3,8-11).

The Specialization Board of Medicine in Turkey by 2017 in the Emergency Medicine Residency Training Core Curriculum recommends at least $4 \mathrm{~h}$ per week of education offered in the department, $4 \mathrm{~h}$ practical (per patient visit is like a simulation laboratory) at least monthly with the need to include education and trainers. Training of $2 \mathrm{~h}$ should be given under the supervision of an educator or emergency medicine specialist.

During the Coronavirus disease-2019 (COVID-19) outbreak, service provision increased in hospitals and emergency departments. Concurrently, improvement in the face-to-face theoretical training for emergency and residents working in the emergency department has become necessary due to social isolation and contact and limited residency training duration, thus deficiencies were tried to be remedied by distance education $(12,13)$. This study aimed to determine the satisfaction level of emergency physicians with the learning model in distance education and the factors that affect their satisfaction levels. Additionally, the study will guide the efforts to eliminate the factors that cause dissatisfaction and avoid disruption of the continuity of residency training in pandemic circumstances.

\section{METHODS}

\section{Study Design}

The study University of Health Sciences Turkey, Bakırköy Dr. Sadi Konuk Training and Research Hospital questionnairebased cross-sectional study that was conducted between June 6, 2020, and August 25, 2020, after approval from the local ethics committee (2020/270).

\section{Population}

Maximum diversity sampling is aimed at our study, which was conducted with emergency physicians (emergency medicine residents and specialists) who experienced e-learning in their departments of different ages and experiences. Emergency medicine specialists who work in institutions that do not provide specialty training or who do not participate in department training or those who refuse to participate in the survey were excluded from the study.

Google forms were used due to the social distance precautions in the pandemic. The questionnaire form was delivered to the participants via emergency medical associations' mail groups and social media groups. The questionnaire form was sent to emergency medicine departments $(n=308)$ that provide distance education, wherein 79 responded. A total of 74 responses were included in the analysis, excluding five physicians who only provided emergency medical training to staff or students (interns, nurses, and paramedics) other than emergency medicine residents. Consent information was taken from all participants.

\section{Data Collection}

Our study chose the online survey method since it provides an easy way to access departments and clinics that started e-learning during the pandemic.

The questionnaire form consists of structured questions, which were prepared based on Likert's 5-level answers as "strongly agree," "agree," "neither agree nor disagree," "disagree," and "strongly disagree."

Since they have not been studied before in the population with emergency medicine training, the scale framework questions were designed in the previously analyzed studies for reliability and validity $(2,3,9)$. The questionnaire form was sent to 20 emergency medicine residents for a pilot 
study, and incomprehensible and misunderstood erroneous questions were corrected with the feedbacks. Responses and participants were not involved in the study analysis.

The questionnaire form consists of 3 parts. The contents of the questions in the sections are given below:

\section{Section 1}

A- Demographic characteristics (gender, age, title, marital status, number of children, and tenure)

B1- Computer usage knowledge level

B2- Distance education knowledge levels (presence of experience and environment)

\section{Section 2}

C1- Self-efficacy levels (using distance education, management, and content management)

C2- Perception of Anxiety (mood characteristics of distance education on the person)

C3- Perception of Interactivity (perceptions about interactions during distance education)

C4- Satisfaction perceptions (distance education module, course content, and interactions)

C5- Benefit perceptions (benefits of distance education and their thoughts on its future use)

C6- Self-control perceptions (self-learning and usability)

C7- Perception of ease of use of the system

\section{Section 3}

\section{C8- General views and attitudes}

These statements are shown in the Supplementary document.

Self-efficacy, anxiety, satisfaction, utility perception, ease of use, and attitude scores are calculated with total Likert points of questions (raw) for each score. Every question has a minimum point of 1 and a maximum of 5. Afterward, the median interquartile range (IQR) was analyzed for each score.

\section{Statistical Analysis}

Numerical variables were represented as mean \pm standard deviation or median (IQR). Attribute variables were shown with numbers and percentages. The Shapiro-Wilks and Kolmogorov-Smirnov tests determined the distribution of the groups. The self-efficacy, satisfaction, interactivity, ease of use perception, benefit perception, self-control, and attitude scores were calculated based on the total 5-level Likert points. For each score, independent groups were evaluated using the independent t-test, the Mann-Whitney
U test, and the Kruskal-Wallis tests. The relationship between attribute variables was evaluated using the chi-square test. The Spearman test and partial correlations were used in the correlation analysis according to data distribution. The Statistical Package for the Social Sciences $®$ for Windows version 23.0 program was used for statistical analysis. Statistical significance level was accepted as p-values of $<0.05$.

\section{RESULTS}

\section{Reliability Analysis}

The reliability analysis result of the statements made revealed a >0.90 (0.965) Cronbach's alpha coefficient (Table 1).

Expressions C102, C104, C83, and c100 were excluded from the analysis due to loading on more than one factor. Kaiser-Meyer-Olkin (KMO and Bartlett's test) test was 0.716 $(p<0.001)$

This study included 74 participants, with a median age of 30 years (IQR=5), wherein 44 (59.5\%) were males and $30(40.5 \%)$ were females. The median (IQR) of each total score and the descriptive data of participant demographics are shown in Table 2. No statistical difference was found between the groups in terms of gender, title, marital status, and the number of children regarding the scores in self-efficacy, Satisfaction, Interactivity, Perception of Benefit, Self-control, Ease of use perception, Anxiety, and Attitude ( $p>0.05$, Mann-Whitney U).

Experience in years showed statistically higher satisfaction $(p=0.018)$, self-control $(p=0.003)$, ease of use $(p=0.042)$, benefit perception $(p=0.022)$, and attitude $(p=0.030)$ rates in residents. However, experience in years is not statistically

Table 1. Reliability analysis for statements and categories

\begin{tabular}{lllll}
\hline & $\begin{array}{l}\text { Cronbach's } \\
\text { alpha }\end{array}$ & Variance & $\begin{array}{l}\text { Standard } \\
\text { deviation }\end{array}$ & Mean \\
\hline Self-efficacy (C1) & 0.947 & 21.884 & 4.678 & 12.92 \\
\hline Anxiety (C2) & 0.932 & 25.094 & 5.009 & 9.69 \\
\hline Interactivity (C3) & 0.909 & 34.135 & 5.843 & 16.31 \\
\hline Satisfaction (C4) & 0.931 & 24.978 & 4.998 & 13.62 \\
\hline $\begin{array}{l}\text { Perception of } \\
\text { benefit (C5) }\end{array}$ & 0.972 & 59.123 & 7.689 & 21 \\
\hline $\begin{array}{l}\text { Self-regulation } \\
\text { (C6) }\end{array}$ & 0.953 & 37.458 & 6.120 & 16.53 \\
\hline $\begin{array}{l}\text { Ease of use (C7) } \\
0.972\end{array}$ & 31.343 & 5.599 & 13.16 \\
\hline $\begin{array}{l}\text { General views } \\
\text { and attitudes (C8) }\end{array}$ & 0.947 & 494.661 & 22.241 & 76.45 \\
\hline
\end{tabular}


Table 2. Demographical data and scores of the participants

\begin{tabular}{|c|c|c|}
\hline & $\mathrm{n}=74$ & n (\%) \\
\hline Age (median \pm SD) & $30(\mathrm{IQR}=5)$ & \\
\hline \multirow{2}{*}{ Gender } & Female & 30 (40.5\%) \\
\hline & Male & $44(59.5 \%)$ \\
\hline \multirow{2}{*}{ Marital status } & Single & $36(48.6 \%)$ \\
\hline & Married & 38 (68.9\%) \\
\hline \multirow{2}{*}{ Children } & 0 & $51(31.1 \%)$ \\
\hline & 1 & $23(30.8 \%)$ \\
\hline \multirow[b]{2}{*}{ Institute } & University & $34(72.3 \%)$ \\
\hline & $\begin{array}{l}\text { Training and } \\
\text { research hospital }\end{array}$ & $13(27.7 \%)$ \\
\hline \multirow{2}{*}{ Degree } & Resident & 55 (74.3\%) \\
\hline & Specialist & 19 (25.7\%) \\
\hline \multirow{5}{*}{ EM residency year } & $0-12 \mathrm{~m}$ & $10(17.9 \%)$ \\
\hline & $13-24 \mathrm{~m}$ & $12(21.4 \%)$ \\
\hline & $25-36 \mathrm{~m}$ & $10(17.9 \%)$ \\
\hline & $37-48 \mathrm{~m}$ & $16(28.6 \%)$ \\
\hline & $48 \mathrm{~m}+$ & $8(14.3 \%)$ \\
\hline \multirow{4}{*}{ Experience as specialist } & $0-2$ years & $1(4.8 \%)$ \\
\hline & $3-4$ years & $6(28.6 \%)$ \\
\hline & $5-8$ years & $8(38.1 \%)$ \\
\hline & $9+$ & $6(28.6 \%)$ \\
\hline \multirow{4}{*}{ Computer Use Skills } & Beginner & $6(8.1 \%)$ \\
\hline & Medium & $35(47.3 \%)$ \\
\hline & Very Good & $11(14.9 \%)$ \\
\hline & Advanced & $22(29.7 \%)$ \\
\hline \multirow[t]{2}{*}{ E-learning experience } & No & $34(51.4 \%)$ \\
\hline & $\begin{array}{l}\text { Yes } \\
\text { Listened } \\
\text { Presented } \\
\text { Both }\end{array}$ & $\begin{array}{l}40(48.6 \%) \\
28(37.8) \\
2(2.7 \%) \\
10(13.5 \%)\end{array}$ \\
\hline Following the lectures & $\begin{array}{l}\text { Yes } \\
\text { No } \\
\text { Sometimes }\end{array}$ & $\begin{array}{l}44(59.5 \%) \\
2(2.7 \%) \\
28(37.8 \%)\end{array}$ \\
\hline Offline use & $\begin{array}{l}\text { Yes } \\
\text { No }\end{array}$ & $\begin{array}{l}15(20.3 \%) \\
59(79.7 \%) \\
\end{array}$ \\
\hline Score & Median (IQR) & \\
\hline Self-efficacy score & $12 /(\mathrm{IQR}=9)$ & \\
\hline Anxiety score & $10(\mathrm{IQR}=11)$ & \\
\hline Satisfaction score & $12 \mathrm{IQR}=12)$ & \\
\hline Perception of utility score & $18(\mathrm{IQR}=15.50)$ & \\
\hline Ease of use score & $11(\mathrm{IQR}=12)$ & \\
\hline Attitude score & $61.5(\mathrm{IQR}=33.25)$ & \\
\hline
\end{tabular}

significant regarding the scores in specialists $(p>0.05$, Kruskal-Wallis).

The rate of previous distance education experience was $48.6 \%(n=40)$. Participants experienced a statistically lower self-efficacy in e-learning $(p=0.044)$ and higher ease of use perception $(p=0.034)$. Experience in e-learning is not statistically significant among the groups regarding satisfaction $(p=0.059)$.

Considering the computer use skills, participants in beginner and medium levels (low computer use skills) were 41 (55.4\%), whereas $33(44.6 \%)$ in very good and advanced (high computer use skills) levels. Self-efficacy $(p=0.960)$, interactivity $(p=0.096)$, satisfaction $(p=0.051)$, and anxiety $(p=0.361$ ) scores were not different between low and high computer use skills. Benefit perception $(p=0.009)$, selfcontrol ( $p=0.006)$, ease of use perception $(p=0.01)$, and attitude $(p=0.018)$ was statistically higher in high computer skill levels.

The most commonly used distance education portal was Zoom ( $n=53,85 \%)$ followed by GoToMeeting ( $n=9,14.1 \%)$, Skype ( $n=9,14.1 \%)$, Microsoft Teams ( $n=5,7.9 \%)$, Moodle $(n=2,3.1 \%)$, and others. Majority of the users learned the distance education portals while using $(n=40,63.5 \%)$, followed by friends and colleagues $(n=23,36.5 \%)$, and via internet and videos $(n=19,30.2 \%)$.

In addition to emergency medicine residency training, the trainees were 6th-grade medical students $(n=6$, $22.2 \%$ ) and other health personnel (nurse, paramedic, and undergraduate students) ( $n=5,18.5 \%)$.

The places where the participants followed the distance education were home $(n=71,95.9 \%)$, hospital $(n=44,59.5 \%)$, vehicle $(n=20,27 \%)$, and other $(n=10,13.5 \%)$, respectively.

The rate of following the lessons with distance education was $60.2 \%$, of whom $73.2 \%$ ( $n=52$ ) listened carefully to all the lessons, $8.5 \%(n=6)$ pretended to listen, and 31\% ( $n=22)$ appeared online but deal with other things.

The most common reason for not attending the course was because of duty and post-seizure $(83.9 \%$ and $51.6 \%$, respectively). Only $20.3 \%$ of the lessons not attended have listened offline.

The most appropriate course time was chosen between 08.00-12.00 and $13.30-17.00$ by the participants (36.4\% and $33.8 \%$, respectively). The majority of participants preferred the lesson duration to be between 20-40 min (41.9\%). The choice of lesson hours that can be rested daily mainly was 2 (58.1\%) and 3 (24.3). The proportion of those who wanted 
their education to be remote in the other year was $79.7 \%$. The preferred frequency of distance education was mostly (60.9\%) once a week.

\section{Correlation Analysis}

Correlation Analysis is shown in Table 3.

- Self-control has also shown a high degree of positive correlation $[r=0.840,95 \%$ confidence interval $(\mathrm{Cl})$ : $0.754-$ 0.898] with the perception of benefit.

- Attitudes showed a high positive correlation with ease of use perception ( $r=0.728,95 \% \mathrm{Cl}$ : 0.595-0.823).

- Self-efficacy showed medium positive correlation with interactivity ( $r=0.498)$, satisfaction $(r=0.407)$ and perception of benefit ( $r=0.415,95 \% \mathrm{Cl}$ : 0.199-0.592).

- There is a very high degree positive correlation between satisfaction and self-control $(r=0.796)$ and perception of benefit ( $r=0.861,95 \% \mathrm{Cl}: 0.784-0.911)$. Satisfaction has a positive correlation with self-control $(r=0.543, p=0.000$, partial correlation) and perception of benefit $(r=0.543$, $p=0.000$, partial correlation).

\section{DISCUSSION}

Our study revealed that perceptions, such as self-efficacy, Satisfaction, Interactivity, Benefit, Self-control, Ease of use, Anxiety, and Attitude, were examined in participants who experienced distance learning in emergency medicine education.

As a result, third and fourth-year residents were highly satisfied with distance education. Satisfaction scores were not affected by the institution, title, gender, and marital status.

Our study revealed no significant difference between the institutions in terms of self-efficacy in distance education. Therefore, all institutions that provide emergency medicine residency training are suitable for distance education.

Our study revealed that emergency physicians were satisfied with the content and functions of distance education and the multimedia environment. A study in medical students, nurses, and paramedics who received emergency medicine education divided the satisfaction into three groups: video, interactive video, and non-animated training, conducted a satisfaction survey with "before and after" questionnaires

Table 3. Spearman correlation analysis of sections

\begin{tabular}{|c|c|c|c|c|c|c|c|c|c|}
\hline & & Self-efficacy & Anxiety & Interactivity & Satisfaction & $\begin{array}{l}\text { Perception } \\
\text { of benefit }\end{array}$ & $\begin{array}{l}\text { Self- } \\
\text { control }\end{array}$ & $\begin{array}{l}\text { Ease of } \\
\text { use }\end{array}$ & Attitudes \\
\hline \multirow{2}{*}{ Self-Efficacy } & rho & 1 & - & - & - & - & - & - & - \\
\hline & & - & - & - & - & - & - & - & - \\
\hline \multirow{2}{*}{ Anxiety } & rho & $-0.244^{\star}$ & 1 & - & - & - & - & - & - \\
\hline & $\mathrm{p}$ & 0.036 & - & - & - & - & - & - & - \\
\hline \multirow{2}{*}{ Interactivity } & rho & $0.498^{\star *}$ & $-0.361^{\text {** }}$ & 1 & - & - & - & - & - \\
\hline & $\mathrm{p}$ & 0.000 & 0.002 & - & - & - & - & - & - \\
\hline \multirow{2}{*}{ Satisfaction } & rho & $0.407^{\star \star}$ & $-0.324^{\star *}$ & $0.421^{\star *}$ & 1 & - & - & - & - \\
\hline & $\mathrm{p}$ & 0.000 & 0.005 & 0.000 & - & - & - & - & - \\
\hline \multirow{2}{*}{$\begin{array}{l}\text { Perception of } \\
\text { benefit }\end{array}$} & rho & $0.415^{\star *}$ & $-0.291^{*}$ & $0.531^{\star \star}$ & $0.861^{\star \star}$ & 1 & - & - & - \\
\hline & $p$ & 0.000 & 0.012 & 0.000 & 0.000 & - & - & - & - \\
\hline \multirow{2}{*}{ Self-control } & rho & $0.397^{\star \star}$ & $-0.351^{\star *}$ & $0.439^{\star \star}$ & $0.796^{\star \star}$ & $0.840^{\star *}$ & 1 & - & - \\
\hline & $\mathrm{p}$ & 0.000 & 0.002 & 0.000 & 0.000 & 0.000 & - & - & - \\
\hline \multirow{2}{*}{ Ease of Use } & rho & $0.290^{* *}$ & $-0.314^{\star *}$ & $0.486^{\star *}$ & $0.434^{\star \star}$ & $0.549^{* *}$ & $0.458^{* *}$ & 1 & - \\
\hline & $\mathrm{p}$ & 0.012 & 0.007 & 0.000 & 0.000 & 0.000 & 0.000 & - & - \\
\hline \multirow{2}{*}{ Attitudes } & rho & 0.192 & $-0.241^{\star}$ & $0.550^{\star \star}$ & $0.550^{\star \star}$ & $0.612^{\star *}$ & $0.594^{\star \star}$ & $0.728^{\star \star}$ & 1 \\
\hline & $\mathrm{p}$ & 0.102 & 0.039 & 0.000 & 0.000 & 0.000 & 0.000 & 0.000 & - \\
\hline
\end{tabular}


and revealed a high satisfaction in all groups (14). Thus, distance education can be an alternative to face-to-face in terms of theoretical training.

After the web-based preparation of the emergency medicine residency curriculum, a 1-year follow-up and satisfaction study revealed that $83 \%$ of emergency medicine residents were satisfied despite technical difficulties (15). Participation has increased compared to the previous year; however, no comparison was made in our study in the participation with previous years. Additionally, the high levels of satisfaction suggest that the online education model may be included in our education system in the future although it is still in its initial stage. Another indication of their satisfaction with the online training is that most participants (79.7\%) want the online training to continue.

Participants experienced a statistically lower self-efficacy $(p=0.044)$ and higher ease of use perception $(p=0.034)$ in e-learning. Compatible with the literature, higher selfefficacy results with decreased experience can be explained by the Dunning Kruger effect (16). This effect is called the inability to acknowledge the individual lack of competence.

Distance education satisfaction studies regarding emergency medicine are limited in the literature. Mueller et al. (17) has presented their online academic emergency medicine experiences during the COVID-19 pandemic and reported that $80 \%$ of courses were conducted successfully. Nevertheless, online education satisfaction has not been included in the study.

Ease of use associated with experience and computer use skills also positively correlates with attitudes toward e-learning. We found that self-control and benefit perception are correlated with satisfaction.

Easy accessibility of distance education has shown a numerically higher level of satisfaction for married couples and participants with children. This situation was also revealed in a study conducted on nurses' satisfaction levels with distance education (9). Our study revealed high rates in married and those with children satisfaction levels. Similar results were obtained in the study conducted by Xing et al. (9) on nurses, which suggests that especially advanced-age peer training can also be provided on online platforms.

Marital status and social responsibilities in having children may cause disruptions in face-to-face education participation and following the lessons from time to time. Our study concluded that having a child and marital status did not affect following online classes. Therefore, online training is more acceptable and traceable in social life.
Additionally, our study received feedback from the participants about the time, frequency, and online training duration, which help in planning optimum online training.

Our study is the first to evaluate online education in emergency medicine residency training, thus we believe it will be a resource for future training and studies.

\section{Study Limitations}

The study included 2 months during the epidemic period. Distance education experiences may have been chosen or started as mandatory and acutely due to the epidemic since it is unclear whether the preparation, distance education portal training, training delivery, and a necessary separate curriculum may affect the satisfaction levels. Under normal circumstances, measurements can be repeated. Another study limitation was the different e-learning platforms. Thus, future studies may investigate the differences among the e-learning platforms regarding software used, quality of internet connection, duration of lessons, the experience of speakers, etc. The study was conducted during the COVID-19 pandemic, thus the low number of distance education clinics may have caused the return of the survey due to the low number of participants and the intensity of the pandemic conditions.

\section{CONCLUSION}

Increasing self-efficacy correlates with benefit perception, associated with higher computer skill levels, satisfaction, and interactivity perception. Increasing the interactivity, advancing user computer skills, augmenting the experience to maintain higher self-efficacy and benefit perception, and increasing satisfaction and adaptation of trainees to e-learning in mandatory conditions pandemic is essential. This study will elucidate the perceptions of distance education that affect attendance and patient care quality for further studies.

\section{ETHICS}

Ethics Committee Approval: The study University of Health Sciences Turkey, Bakırköy Dr. Sadi Konuk Training and Research Hospital questionnaire-based cross-sectional study that was conducted between June 6, 2020, and August 25,2020 , after approval from the local ethics committee (2020/270).

Informed Consent: Consent information was taken from all participants.

\section{Authorship Contributions}

Concept: G.B.B., H.D., Design: G.B.B., B.I., Data Collection or Processing: G.B.B., B.I., Analysis or Interpretation: G.B.B., B.I., Literature Search: G.B.B., Writing: G.B.B. 
Conflict of Interest: No conflict of interest was declared by the authors.

Financial Disclosure: The authors declared that this study received no financial support.

\section{REFERENCES}

1. Moore JL, Dickson-Deane C, Galyen K. e-Learning, online learning, and distance learning environments: Are they the same? The Internet and Higher Education 2011;14:129-35.

2. Begi mbetova K. Uzaktan eğitimde öğretim elemanı ve öğrencilerin memnuniyet düzeyi. Ankara: Gazi Üniversitesi, Bilişim Enstitüsü, Yönetim Bilişim Enstitüsü Anabilim Dalı, Yayınlanmamış Yüksek Lisans Tezi Ankara; 2015.

3. Isik O. E-learning satisfaction factors. Dans: Proceedings of the 39th Annual Meeting of the Decision Sciences Institute; 2008.

4. Doménech-Betoret F, Abellán-Roselló L, Gómez-Artiga A. SelfEfficacy, Satisfaction, and Academic Achievement: The Mediator Role of Students' Expectancy-Value Beliefs. Front Psychol 2017;8:1193.

5. Oliver RL. Satisfaction: a behavioral perspective on the consumer. 2nd ed. Armonk NY: M.E. Sharpe; 2010.

6. Bandura A. Self-efficacy: the exercise of control. New York: W.H. Freeman; 1997.

7. Leung Y. Perceived Benefits. In: Gellman MD, Turner JR, editors. Encyclopedia of Behavioral Medicine. New York, NY: Springer New York; 2013.

8. Davis FD. Perceived Usefulness, Perceived Ease of Use, and User Acceptance of Information Technology. MIS Quarterly 1989;13:31940.
9. Xing W, Ao L, Xiao H, Liang L. Chinese Nurses' Preferences for and Attitudes About e-Learning in Continuing Education: A Correlational Study. J Contin Educ Nurs 2020;51:87-96.

10. Ilgaz H, Aşkar P. The Contribution of Technology Acceptance and Community Feeling to Learner Satisfaction in Distance Education. Procedia-Social and Behavioral Sciences 2013;106:2671-80.

11. Strong R. Investigating Students' Satisfaction with eLearning Courses: The Effect of Learning Environment and Social Presence. Journal of Agricultural Education 2012;53:98-110.

12. Pek JH, Low JWM, Lau TP, Gan HN, Phua DH. Emergency medicine residency training during COVID-19. Singapore Med 2020. DOI: 10.11622/smedj.2020139

13. Mufti A, Maliyar K, Sachdeva M, Doiron P. Modifications to dermatology residency education during the COVID-19 pandemic. J Am Acad Dermatol 2020;83:235-6.

14. Leszczyński P, Gotlib J, Kopański Z, Wejnarski A, Świeżewski S, Gałązkowski R. Analysis of Web-based learning methods in emergency medicine: randomized controlled trial. Arch Med Sci 2018;14:687-94.

15. Kornegay JG, Leone KA, Wallner C, Hansen M, Yarris LM. Development and implementation of an asynchronous emergency medicine residency curriculum using a web-based platform. Intern Emerg Med 2016;11:1115-20.

16. Zawadka M, Graczyńska A, Janiszewska A, Ostrowski A, Michałowski M, Rykowski M, et al. Lessons Learned from a Study of the Integration of a Point-of-Care Ultrasound Course into the Undergraduate Medical School Curriculum. Med Sci Monit 2019;25:4104-9.

17. Mueller M, Schriefl C, Holzer M, Roeggla M, Laggner AN, Ettl F. Education in Academic Emergency Medicine During the COVID-19 Pandemic - Our Experience From an Ongoing Crisis. Front Public Health 2020;8:592503. 